\title{
More to Phaeovirus infections than first meets the eye
}

Article

Published Version

Creative Commons: Attribution-Noncommercial 4.0

Open Access

Schroeder, D. C. (2015) More to Phaeovirus infections than first meets the eye. Perspectives in Phycology, 2 (2). pp. 105109. ISSN 2198-011X doi:

https://doi.org/10.1127/pip/2015/0034 Available at https://centaur.reading.ac.uk/79450/

It is advisable to refer to the publisher's version if you intend to cite from the work. See Guidance on citing.

Published version at: http://dx.doi.org/10.1127/pip/2015/0034

To link to this article DOI: http://dx.doi.org/10.1127/pip/2015/0034

Publisher: E Schweizerbart Science Publishers -

All outputs in CentAUR are protected by Intellectual Property Rights law, including copyright law. Copyright and IPR is retained by the creators or other copyright holders. Terms and conditions for use of this material are defined in the End User Agreement.

\section{www.reading.ac.uk/centaur}

\section{CentAUR}

Central Archive at the University of Reading

Reading's research outputs online 


\title{
More to Phaeovirus infections than first meets the eye
}

\author{
Declan C. Schroeder
}

The Marine Biological Association Citadel Hill, Plymouth, PL1 2PB, United Kingdom

\author{
With 1 figure and 1 table
}

\begin{abstract}
Phaeoviruses infect the brown algae, Phaeophyceae. They exploit a Persistent evolutionary strategy via genome integration and are the only known representatives to do so amongst the giant viruses, Megaviridae. This review brings together for the first time new knowledge on phaeovirus prevalence and alternative strategies of infection, and highlights how exceptional phaeoviruses are compared to most host-virus systems. Given what we now know about phaeoviruses, unlocking the hidden diversity within other seaweed systems has the potential to fundamentally change concepts within Virology, while significantly impacting on the seaweed industry.
\end{abstract}

\section{Introduction}

A key discovery towards the end of the $20^{\text {th }}$ century that over a million viruses can be found in every millilitre of seawater (Bergh et al. 1989) has led to the resurgence of arguably the most dynamic and rapidly evolving branch of virology, Aquatic Viral Ecology (Fuhrman 1999). Many new orders and families of aquatic viruses have since been discovered (Labonte \& Suttle 2013) and more are predicted to emerge as we gain an even greater understanding of the biodiversity in our oceans (e.g. http://www.microb3.eu/). To put the aforementioned discovery into context, our knowledge of viruses infecting marine algae can be dated as far back as the late $19^{\text {th }}$ century with the first descriptions of abnormal or deformed reproductive organs (e.g. Fig. 1) in the small filamentous brown macroalga Ectocarpus (Sauvageau 1896). This observation coincided with Ivanovsky's seminal work in 1892; the first experiments defining the filterable infectious agents as viruses, which was later verified by Beijerinck in 1898 (Lechevalier 1972). Sauvageau (1896) was unaware that viruses were responsible for these deformities but, nonetheless, speculated that it could be due to a parasite. Many years later, with the application of electron microscopy, confirmation came that these deformities were indeed due to a virus, named Ectocarpus siliculosus virus (EsV-1) (Müller et al. 1990). Continued efforts by two independent laboratories, headed by and linked to Müller and Meints, led to the further characterisation of many more examples of phaeoviruses infecting other members of the order Ectocarpales (Table 1). Here I will give my perspective on how the application of advances in molecular technologies has challenged our understanding of established concepts in the field of Virology. I will expand on two key findings that propose phaeoviruses use a genome reduction strategy to widen their host range to beyond the filamentous brown ectocarpoids and that a legacy of this range expansion is multiple infections.

\section{Multiple infections as a result of host range expansion}

Viruses are obligate parasites and therefore require a cellular environment for their propagation. Successful viruses have found a way to co-exist with their hosts and stable infections often have a long co-evolutionary history with specific hosts. This co-evolution leads to a unique relationship that results in a species, or even strain, specificity of the virus which can make transmission to other hosts (even within species) very difficult. Thus, natural host range expansions by viruses are rare events. However, when they do occur disease outbreaks can become devastating because the viruses often spread through non- adapted host populations. Two notable examples of these are HIV and Ebola where the virus has spread from infected wild animals such as chimpanzees to humans (Hahn et al. 2000; Chowell \& Nishiura 2014).

Eukaryotic algal dsDNA viruses fall within two families, the Phycodnaviridae (Wilson et al. 2005) and the Mimiviridae (Raoult et al. 2004). Both share a common ancestor and are often collectively referred to as NucleoCytoplasmic Large DNA Viruses (NCLDVs) (Yutin et al. 2009). More recently the terms "Giant viruses" or "Giruses" have been used to emphasize the relative size of the NCDLVs in comparison to those viruses that commonly infect plants and animals (Ogata et al. 2009). That said, both these viral families share many features of other eukaryotic viruses, which include the Poxviridae, Iridoviridae, Ascoviridae, Asfarviridae, and Marseilleviridae, and for that reason a new order Megavirales has been proposed (Colson et al. 2013). 
A

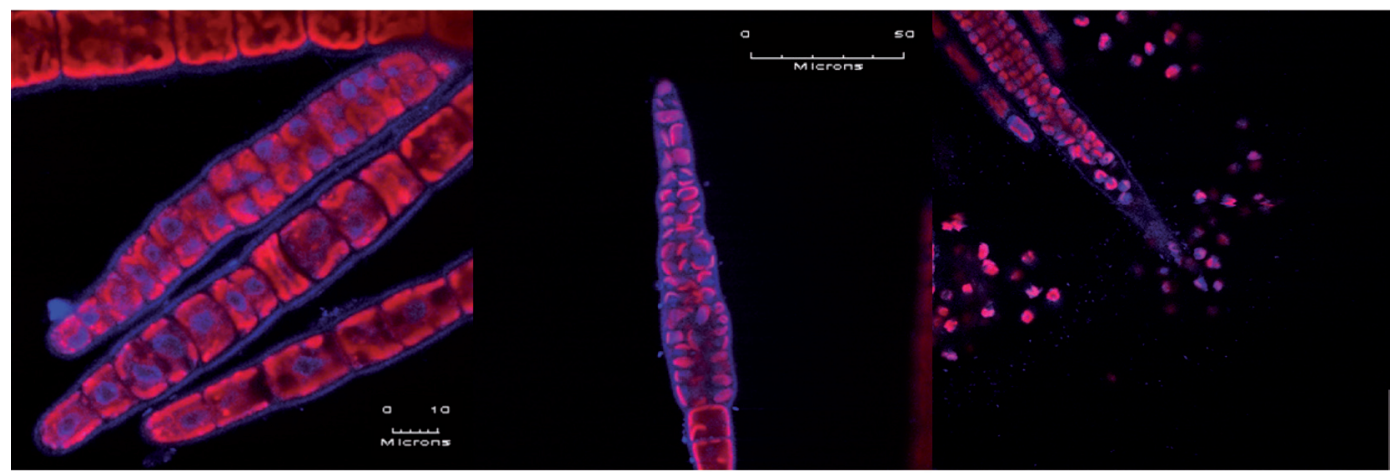

B

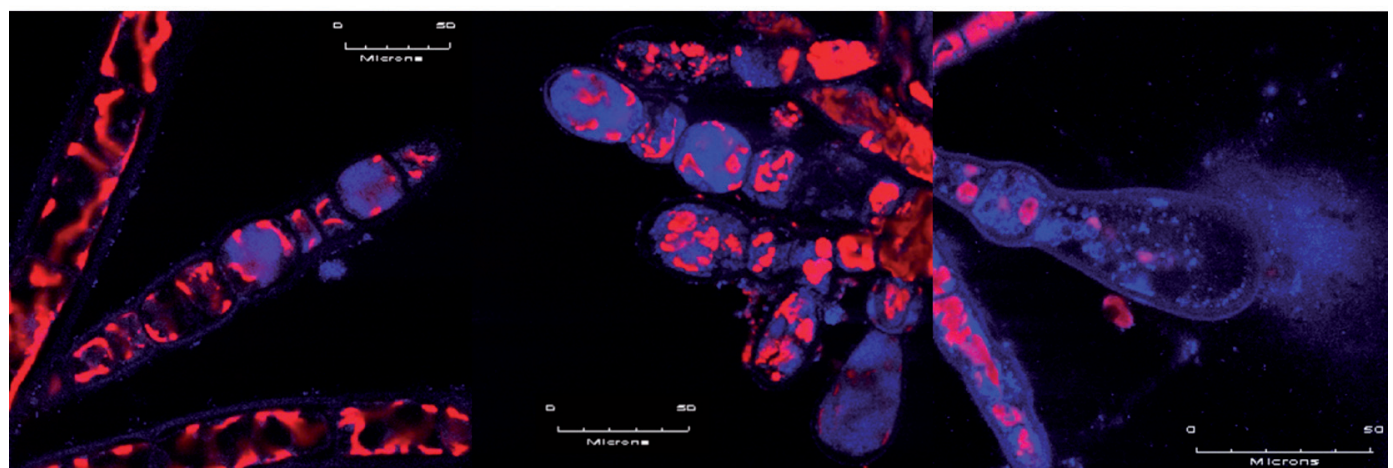

Fig. 1. Epi-fluorescence microscope images of E. siliculosus depicting zoidangium development. (A) From left to right, different developmental stages of zoidangium development to zoid release. The pink stained individual zoids (combination of DAPI stained blue DNA and red auto-fluorescence from nuclei and chloroplasts, respectively) are clearly visible. (B) From right to left, EsV-1 induction in the zoidangium resulting in misshapen and heavily stained virus filled cells.

The Phycodnaviridae consists of six genera: Chlorovirus, Coccolithovirus, Prasinovirus, Prymnesiovirus, Phaeovirus, and Raphidovirus, so named because virus classification in this family of viruses is linked to the taxonomy of their hosts.

Phaeovirus contain members that represent the only characterised genus to infect the brown macroalgal order Ectocarpales, which contribute significantly to primary production in coastal waters and estuaries, worldwide. Given the diversity of the many known species of all macroalgae in the world, i.e. not only browns but greens and reds as well, there is a lack of knowledge of the prevalence and range of virus infections in these taxa (Schroeder 2011). A limited screening program for phaeoviruses in other members of the class Phaeophyceae has revealed that virus infections may be a general feature of the entire class (unpublished data). This study utilised a relatively new application of real time PCR where amplified products are denatured along a temperature gradient and unique melting curves distinguish between genotypes within complex populations. This technique is known as High Resolution Melt or HRM (Al-Kandari et al. 2011; Li et al. 2014). HRM was used in my lab to observe for the first time that phaeoviruses infect three common European kelp species, namely Laminaria digitata, L. hyperborea and Saccharina latissimi (Table 1). This is the first indication that algal viruses can jump across taxonomic orders. If this study was extended to look at the other macroalgal viruses, how common would this phenomenon be?

Phaeoviruses have evolved a stable co-existence with their ectocarpoid hosts. This is because they follow a persistent viral life strategy, seldom causing disease and with transmission often from adults through deformed reproductive organs to the spores and gametes (collectively referred to as zoids) of a susceptible ectocarpoid host (Müller et al. 1998). Genome sequence analysis of three phaeoviruses, EsV-1, FirrV-1 and FsV-158, revealed that a central core set of genes are maintained (Schroeder et al. 2009). Sequence and gene phylogenies for three phaeovirus core single copy genes (Stevens et al. 2014) revealed that these viruses can be split into two subgroups (A \& B), with A representing a single virus genotype - host relationship (Stevens et al. 2014) containing the type virus EsV-1 and four other phaeoviruses infecting different genera of ectocarpoids (Table 1). Subgroup B on the other hand contain viruses representing multiple virus genotypes - host infections (Ivey et al. 
1996; Stevens et al. 2014) and appear to be restricted to the ectocarpoid genus, Feldmannia (Table 1). In addition, the jumping of a virus of subgroup A into the Feldmannia species led to a dramatic genome reduction, with as much as half of a genome equivalent loss (Table 1). This genome loss could also explain the apparent rapid host expansion in the Laminariales. In contrast to other much publicised host range expansion events, few or no disease outbreaks directly assigned to virus infection has emerged or been reported for kelps. That said, the increase in demand for seaweed products has seen a steady increase in algal aquaculture activities, with a resultant increase in losses due to disease (Gachon et al. 2010). Because of the latent nature of Phaeovirus infection, some of these losses could be due to viruses, especially if no molecular tools were used to determine the causative agent. The need to isolate and characterise phaeoviruses, or for that matter any other virus, in kelp systems is therefore both timely and of ecological and economic importance.

The multiple infections by the subgroup B viruses, especially in Feldmannia simplex, has revealed that up to 8 closely related, but distinct, FlexV's can be found in its genome (Stevens et al. 2014). This observation challenges the Superinfection exclusion (SIE) phenomenon commonly reported in many bacterial and plant virus systems. SIE posits that a virus excludes a closely related virus from infecting the same host (Abedon 2015). Moreover, some phage can also integrate like phaeoviruses into the genomes of their hosts. These lysogenic or temperate phage provide the host with a fitness benefit because they actively prevent other, often lytic, phage from lysing the host. What is the benefit to Feldmannia simplex in having eight viral genomes inserted into its genome? This is especially puzzling as transcriptomic experiments demonstrate that the provirus in Ectocarpus remains silent (Cock et al. 2010). As in mammal models, could these ectopcarpoid proviruses serve as a source of new transcriptional regulatory regions (van de Lagemaat et al. 2003)? Whatever their roles in the biology of brown seaweeds, we know that new processes are bound to be uncovered if we are bold enough to keep working on them. Moreover, other, less well studied, seaweed viruses have the potential to be even more diverse than the phaeoviruses; they have a more diverse size, shape and genome range than the phaeoviruses (Schroeder 2011). What is becoming clear is that they belong to different families of viruses, thereby extending algal viruses to beyond the phycodna- and mimivirus families.

Table 1. Members of genus Phaeovirus that infects the Phaeophytes.

\begin{tabular}{|c|c|c|c|c|c|}
\hline $\begin{array}{l}\text { Phaeovirus } \\
\text { Subgroup }\end{array}$ & Virus name & $\begin{array}{l}\text { Original Species } \\
\text { of isolation or } \\
\text { detection }\end{array}$ & $\begin{array}{c}\text { Average Virus } \\
\text { genome size } \\
\text { in kbp (std dev) }\end{array}$ & Host range & References \\
\hline \multirow{4}{*}{ A } & EfasV-1 & $\begin{array}{l}\text { Ectocarpus } \\
\text { fasciculatus }\end{array}$ & & & $\begin{array}{l}\text { (Kapp et al. 1997; } \\
\text { Stevens et al. 2014) }\end{array}$ \\
\hline & HincV-1 & Hincksia hincksia & & & \\
\hline & MclaV-1 & $\begin{array}{l}\text { Myriotrichia } \\
\text { claviformis }\end{array}$ & & & \\
\hline & PlitV-1 & Pylaiella littoralis & & & $\begin{array}{l}\text { (Maier et al. 1998; } \\
\text { Stevens et al. 2014) }\end{array}$ \\
\hline \multirow{5}{*}{ B } & FirrV-1 (+ 2 variants) & $\begin{array}{l}\text { Feldmannia } \\
\text { irregularis }\end{array}$ & & & $\begin{array}{l}\text { (Kapp et al. 1997; } \\
\text { Delaroque et al. 2003) }\end{array}$ \\
\hline & FsV-158 (+ 1 variant) & Feldmannia sp. & & & $\begin{array}{l}\text { (Henry \& Meints 1992; } \\
\text { Schroeder et al. 2009) }\end{array}$ \\
\hline & LdigV & Laminaria digitata & TBD & & Unpublished data \\
\hline & LhybV & $\begin{array}{l}\text { Laminaria } \\
\text { hyperborea }\end{array}$ & TBD & & \\
\hline & SlatV & $\begin{array}{l}\text { Saccharina } \\
\text { latissima }\end{array}$ & TBD & & \\
\hline
\end{tabular}

TBD: to be determined 


\section{A latent co-existence}

Phages are the most abundant viruses in marine ecosystems. They can be characterised as being highly virulent, $r$-strategists, acute and lytic pathogens with large burst sizes that rapidly turn-over their bacterial hosts (Suttle 2007). The phycodna- and mimiviruses are another significant, yet smaller, component of the marine viral fraction. They too, mostly, follow an acute life strategy, although their burst sizes are numerically much smaller. Significantly, the phaeoviruses are the only notable exception to this rule as they follow a $K$-selected persistent life strategy (Müller et al. 1998). Free phaeovirus particles infect swimming zoids produced in zoidangia of healthy adult hosts. Upon attachment the zoids stop swimming and settle onto suitable substrata. Importantly, the virus does not kill or lyse the zoids and those that settle develop into adult sporophytes or gametophytes (Müller et al. 1998).

Virus infection takes place in the zoid life stages as they lack the protection of a cell wall. The virus integrates into the genome of the zoid and therefore the resultant adult has one copy of a provirus inserted into every cell. The infected adult often expresses in a gradient of non to absolute overt symptoms (deformed zoidangia). The host-virus relationship has evolved a stable evolutionary co-existence where the host appears for all intents and purposes healthy and the virus exists indefinitely as a provirus. Initiation of infection, i.e. the mechanism of release of the provirus out of the host genome, is still not well understood. Virus particles are exclusively seen in reproductive organs, suggesting that reproductive cells possess unique properties for virus propagation. Epi-fluorescence microscopy reveals that induction occurs before zoid differentiation (Fig. 1). Infection therefore does not appear to spread between zoids within a fully differentiated and developed zoidangium. Instead, virus induction occurs at a very early stage during zoidangium development. It is likely that a trigger within the cell-cycle, i.e. transition from somatic cell to mitotically or meiotically producing zoid cell, could be involved in the induction process. Deformed reproductive structures have been reported to produce in the range of $10^{5}$ to $10^{6}$ viruses per deformed reproductive organ.

Another unusual feature of the subgroup B phaeoviruses is that they have evolved at a similar evolutionary rate as an Acute life strategist, but uniquely retain a Persistent life strategy (Stevens et al. 2014). This study applied a pairwise analysis of the evolutionary divergence in nucleotide sequences within the various groups of phycodnaviruses. It was found that subgroup $\mathrm{B}$ has a median nucleotide divergence range in the DNA polymerase gene fragment, comparable to the ranges of that of the other $r$ - selected lytic phycodnavirus groups. While subgroup A viruses have maintained the classic $\mathrm{K}$ - selection life strategy, they have a much lower divergence range, i.e. about a half of that of subgroup B (Stevens et al. 2014).

\section{Conclusion}

Phaeoviruses share an evolutionary history with other large viruses and raises the question of whether the novel evolutionary features as described here are also prevalent in other related systems. New insights into this group reveal that they can have unusually high mutation rates, multiplicity of infection can be common and that reduction of their giant dsDNA genomes might play a significant part in their unusually large host range. The take home message from what has been learnt to date is that further research into seaweed viral ecology is required and that the phaeoviruses amply demonstrate that our knowledge of Virology more generally is still incomplete.

Acknowledgements: Thanks go to Murray Brown and Daniella Schatz for their helpful suggestions while writing this review. I would also like to thank Sonja Brown for taking the many ectocarpoid fluorescence images that contributed to Figure 1 while doing Molly Spooner Bursary placement with me.

\section{References}

Abedon, S. (2015): Bacteriophage secondary infection. - Virol. Sin.: $1-8$.

Al-Kandari, M.A., Highfield, A.C., Hall, M.J., Hayes, P. \& Schroeder, D.C. (2011): Molecular tools separate harmful algal bloom species, Karenia mikimotoi, from different geographical regions into distinct sub-groups. - Harmful Algae 10: 636-643.

Bergh, O., Borsheim, K.Y., Bratbak, G., Heldal, M. (1989): High Abundance of Viruses Found in Aquatic Environments. - Nature 340: 467-468.

Chowell, G., Nishiura, H. (2014): Transmission dynamics and control of Ebola virus disease (EVD): a review. - BMC Medicine 12: 196.

Cock, J.M., Sterck, L., Rouzé, P., Scornet, D., Allen, A.E. et al. (2010): The Ectocarpus genome and the independent evolution of multicellularity in brown algae. - Nature 465: 617-621.

Colson, P., De Lamballerie, X., Yutin, N., Asgari, S., Bigot, Y., Bideshi, D.K., Cheng, X.-W., Federici, B.A., Van Etten, J.L., Koonin, E.V., La Scola, B. \& Raoult, D. (2013): "Megavirales", a proposed new order for eukaryotic nucleocytoplasmic large DNA viruses. - Archives of Virology 158: 2517-2521.

Delaroque, N., Boland, W., Müller, D.G. \& Knippers, R. (2003): Comparisons of two large phaeoviral genomes and evolutionary implications. - J. Molecular Evolution 57: 613-622.

Delaroque, N., Müller, D.G., Bothe, G., Pohl, T., Knippers, R. \& Boland, W. (2001): The complete DNA sequence of the Ectocarpus siliculosus Virus EsV-1 genome. - Virology 287: 112-132.

Friess-Klebl, A.K., Knippers, R. \& Müller, D.G. (1994): Isolation and characterization of a DNA virus infecting Feldmannia simplex (Phaeophyceae). - J. Phycol. 30: 653-658.

Fuhrman, J.A. (1999): Marine viruses and their biogeochemical and ecological effects. - Nature 399: 541-548. 
Gachon, C.M.M., Sime-Ngando, T., Strittmatter, M., Chambouvet, A. \& Kim, G.H. (2010): Algal diseases: spotlight on a black box. - Trends in Plant Science 15: 633-640.

Hahn, B.H., Shaw, G.M., De, K.M., Cock \& Sharp, P.M. (2000): AIDS as a Zoonosis: Scientific and Public Health Implications. Science 287: 607-614.

Henry, E.C. \& Meints, R.H. (1992): A persistent virus infection in Feldmannia (Phaeophyceae). - J. Phycol. 28: 517-526.

Ivey, R.G., Henry, E.C., Lee, A.M., Klepper, L., Krueger, S.K. \& Meints, R.H. (1996): A Feldmannia algal virus has two genome size-classes. - Virology 220: 267-273.

Kapp, M., Knippers, R. \& Müller, D.G. (1997): New members of a group of DNA viruses infecting brown algae. - Phycol. Res. 45: 85-90.

Labonte, J.M. \& Suttle, C.A. (2013): Previously unknown and highly divergent ssDNA viruses populate the oceans. - ISME J 7: 2169-2177.

Lanka, S.T.J., Klein, M., Ramsperger, U., Müller, D.G. \& Knippers, R. (1993): Genome structure of a virus infecting the marine brown alga Ectocarpus siliculosus. - Virology 193: 802-811.

Lechevalier, H. (1972): Dmitri Iosifovich Ivanovski (1864-1920). Bacteriol. Rev. 36: 135-145.

Li, M., Zhou, L., Palais, R.A. \& Wittwer, C.T. (2014): Genotyping Accuracy of High-Resolution DNA Melting Instruments. Clinical Chem. 60: 864-872.

Maier, I., Wolf, S., Delaroque, N., Müller, D.G. \& Kawai, H. (1998): A DNA virus infecting the marine brown alga Pilayella littoralis (Ectocarpales, Phaeophyceae) in culture. - Eur. J. Phycol. 33: 213-220.

Müller, D.G., Kapp, M., Knippers, R., Maramorosch, K., Murphy, F.A. \& Aaron, J.S. (1998): Viruses in marine brown algae. - In: Maramorosch, K., Murphy, F.A. \& Shatkin, A.J. (eds), Advances in Virus Research, pp. 49-67. - Academic Press.

Müller, D.G., Kawai, H., Stache, B. \& Lanka, S. (1990): A virus infection in the marine brown alga Ectocarpus siliculosus (Phaeophyceae). - Bot. Acta 103: 72-82.

Ogata, H., Toyoda, K., Tomaru, Y., Nakayama, N., Shirai, Y., Claverie, J.-M. \& Nagasaki, K. (2009): Remarkable sequence similarity between the dinoflagellate-infecting marine girus and the terrestrial pathogen African swine fever virus. - Virology J. 6: $178-178$.
Raoult, D., Audic, S., Robert, C., Abergel, C., Renesto, P., Ogata, H., Bernard, Suzan, M. \& Claverie, J.-M. (2004): The 1.2-megabase genome sequence of Mimivirus. - Science 306: 1344-1350.

Sauvageau, C. (1896): Sur la nature des sporanges en chapelet de l'Ectocarpus confervoides.

Schroeder, D.C. (2011): Viruses of Seaweeds. - In: Hurst, C. (ed.), Studies in Viral Ecology: Microbial and Botanical Host Systems, p. 208. - Wiley-Blackwell, New Jersey.

Schroeder, D.C., Park, Y., Yoon, H.-M., Lee, Y.S., Kang, S.W., Meints, R.H., Ivey, R.G. \& Choi, T.-J. (2009): Genomic analysis of the smallest giant virus-Feldmannia sp. virus 158. Virology 384: 223-232.

Stevens, K., Weynberg, K., Bellas, C., Brown, S., Brownlee, C., Brown, M.T. \& Schroeder, D.C. (2014): A Novel Evolutionary Strategy Revealed in the Phaeoviruses. - PLos ONE 9: e86040.

Suttle, C.A. (2007): Marine viruses - major players in the global ecosystem. - Nature reviews. Microbiology 5: 801-812.

Van De Lagemaat, L.N., Landry, J.-R., Mager, D.L. \& Medstrand, P. (2003): Transposable elements in mammals promote regulatory variation and diversification of genes with specialized functions. - Trends in Genetics 19: 530-536.

Wilson, W., Van Etten, J.L., Schroeder, D.C., Nagasaki, K., Brussaard, C.P.D., Delaroque, N., Bratbak, G. \& Suttle, C.A. (2005): Phycodnaviridae. In: Fauquet, C.M., Mayo, M.A., Maniloff, U., Dusselberger, L. \& Ball, A. (eds), Virus Taxonomy: Classification and Nomenclature of Viruses, VIIIth ICTV Report. - Elsevier/ Academic Press: London.

Yutin, N., Wolf, Y.I., Raoult, D. \& Koonin, E.V. (2009): Eukaryotic large nucleo-cytoplasmic DNA viruses: Clusters of orthologous genes and reconstruction of viral genome evolution. - Virology J. 6: $223-223$.

Manuscript received: 24 March 2015

Accepted: 17 July 2015

Handling editor: John Bolton 